\title{
Multi-method solutions to the problem of dating early trackways and associated colluvial sequences
}

Article

Accepted Version

Creative Commons: Attribution-Noncommercial-No Derivative Works 4.0

Bell, M., Black, S., Maslin, S. and Toms, P. (2020) Multimethod solutions to the problem of dating early trackways and associated colluvial sequences. Journal of Archaeological Science: Reports, 32. 102359. ISSN 2352-409X doi: https://doi.org/10.1016/j.jasrep.2020.102359 Available at https://centaur.reading.ac.uk/86955/

It is advisable to refer to the publisher's version if you intend to cite from the work. See Guidance on citing.

To link to this article DOI: http://dx.doi.org/10.1016/j.jasrep.2020.102359

Publisher: Elsevier

All outputs in CentAUR are protected by Intellectual Property Rights law, including copyright law. Copyright and IPR is retained by the creators or other copyright holders. Terms and conditions for use of this material are defined in the End User Agreement.

www.reading.ac.uk/centaur 
Central Archive at the University of Reading

Reading's research outputs online 


\section{Multi-method solutions to the problem of dating early trackways and associated colluvial} sequences

M. Bell ${ }^{1}$, S. Black ${ }^{1}$, S. Maslin ${ }^{1}$ and P. Toms ${ }^{2}$

Corresponding author: Martin Bell, ${ }^{1}$ Department of Archaeology, University of Reading,

6 Reading UK, RG6 6AB m.g.bell@reading.ac.uk

2P.Toms, Luminescence Laboratory, University of Gloucestershire, Cheltenham, GL504AZ,

$8 \quad$ UK p.toms@glos.ac.uk

\section{Abstract}

Trackways show how sites linked together as parts of living landscapes. Prehistoric trackways, especially hollow ways, are often regarded as undatable. Where trackways are bounded by early fields, colluvial sediment accumulations can provide dating evidence. The case study of a trackway at Lyminge, Kent, UK is dated using a multi-method strategy, including optically stimulated luminescence, uranium series, molluscs and artefacts, indicating it is of late prehistoric or RomanoBritish origin. This demonstrates that a combination of methods can reveal secure chronologies for trackways, lynchets and other colluvial sediments such as valley fills in many landscapes.

\section{Key Words}

Trackways, hollow way, lynchet, colluvium, uranium series, optically stimulated luminescence, molluscs

\subsection{Introduction}

Trackways provide evidence of patterns of connectivity in past landscapes and enable archaeologists to look beyond the dots on the map which we call sites to the ways in which those places were networked together as parts of living landscapes. Today there is a growing interest in prehistoric mobility as shown by case studies from Britain and Europe (Cummings and Johnson 2007; Leary 2014; Leary and Kador 2016; Preston and Schorle 2013; Bell and Leary 2020) and recognition of the contribution of anthropological perspectives to mobility studies in middle and south America (Snead et al 2009). Interest in ancient routeways derives in part from phenomenological perspectives (Tilley $1994)$ and the realisation that routes through landscape influence perception. Ingold $(2011,12)$ regards movement as 'the primary condition of being or becoming'. Beyond archaeology, Macfarlane (2012) writes about walking as a way of knowing and how our movement through landscape shapes us. Thus routeways can be seen as formative aspects of niche construction (Olding-Smee et al 2003; Laland and O'Brian 2010), whereby a range of organisms, including animals, contribute to the construction of their own niches and that of other organisms. For instance paths, originally established by animals, may be followed by people and vice versa. Routeways may be marked by linear clearings, transplanted plants, plants propagated from faeces and by monuments constructed by people; all contribute to the structuration of landscapes and the ways in which they are encountered and perceived by subsequent generations (Bell 2020). There remains, however, something of a disconnect between a theoretical recognition of the significance of mobility and fieldbased understanding of routeways in the landscape. Trackways have often been considered undatable (Taylor 1979; Hindle 1993) and, whilst landscape archaeological projects increasingly highlight their social significance, there has been no corresponding development of reliable dating methods.

\subsection{Prehistoric trackways}


Some notable empirically-based fieldwork on trackways was published in the first quarter of the twentieth century (Curwen and Curwen 1923; Fox 1923). Bell (2020) argues that this work was nipped in the bud by the publication of Alfred Watkins' (1925) Old Straight Track which promulgated a wholly erroneous view of ancient routeways based on ley lines (Williamson and Bellamy 1983). This served as a Upas tree, poisoning the ground for the study of ancient routeways for almost a century. Instead pioneering prehistorians turned their attention from tracks to settlement excavations. Not so in continental Europe where there has been a different and more productive tradition of trackway research. In Denmark, Germany and the Netherlands there has been an emphasis on alignments of prehistoric sites, mainly barrows as indicating prehistoric routes; many are earlier Bronze Age, some clearly of Neolithic origin (Bakker 1976; 1991; Klassen 2014). In Denmark there has been an emphasis on ancient routeways and a national inventory exists of some 2300 sites (Bang 2013). In so far as British prehistorians focused on routeways, their emphasis has been on ridgeways which follow the axis of upland escarpments. Their prominence arises partly from a twentieth-century role as long distance amenity paths. They were originally identified as ancient because concentrations of prehistoric sites occurred on the ridges; however, it subsequently became evident that prehistoric sites were often equally frequent in lowland and river valley situations where they had been levelled by more intensive later cultivation (Taylor 1979). Two studies of the most well-known ridgeway in Oxfordshire and Wiltshire have addressed the question of origins. At Uffington, Oxfordshire the present ridgeway line cuts across a late Bronze Age linear earthwork and there was no certain evidence of its prehistoric origins (Miles et al 2003). At Overton, Wiltshire the present-day ridgeway overlies 'Celtic' fields and could be of post-Roman origin (Fowler 2000; 1999). At Whitehorse Stones, Kent the ridgeway route, the North Downs / Pilgrims Way, appeared to be no earlier than the Anglo-Saxon period (Booth et al 2011). Several other studies have also questioned the prehistoric significance of the ridgeways including the Jurassic Way (Taylor 1979), the Icknield Way (Harrison 2003), the North Downs Way (Turner 1980) and the South Downs Way (Bell 2020).

Whilst attention has been on the ridgeways there has been much less focus on multiple parallel routeways at right angles to the ridges which link contrasting environmental and topographic zones; these we call 'cross topography routes'. Such routes have been mapped: in Kent by Everett (1986); beside the Lea Valley and elsewhere by Williamson (2008); crossing the Icknield Way by Harrison (2003); and in Sussex by Brandon (1974). These routes have generally been interpreted as drove roads of the medieval period when seasonal animal movements are historically attested (Everitt 1986)

In lowland Britain, particularly in riverine and coastal lowlands, earlier droveways of the later Bronze and Iron Ages have been identified in association with extensive landscapes of co-axial fields (Yates 2007). These also run across the topography, often connecting the resources of higher ground, river terrace and floodplain/ coastal wetland. The most extensively excavated example is Fengate where one of a series of parallel droveways led to the late Bronze Age post alignment/ bridge at Flag Fen (Pryor 2001). Coaxial field systems with associated trackways can be recognised in the present-day landscapes of many parts of Britain; some appear to predate Roman roads and to have elements that are of Roman or earlier origin (Williamson 2008; Rippon et al 2015). At Saltwood Tunnel, Kent coaxial fields with a series of parallel trackways had their origins in the later Bronze Age and Iron Age and here some axial trackways survived into the present-day landscape (Booth et al 2011). However, the relationship between prehistoric cross topography routes, the droveways of coaxial field systems, the medieval droves, surviving coaxial landscapes and the agricultural economies which gave rise to these landscapes remains contentious and in need of further investigation (Oosthuzen 2013; Rippon et al 2015).

\subsection{Hollow ways}


Hollow ways created by erosion along routeways often characterise steeper sections of the cross topography routes. They have received little attention in terms of dating, partly because, as erosive features, they have been considered undatable. The landscape significance and widespread occurrence of hollow ways is increasingly apparent from LiDAR surveys which facilitate the mapping of topographic features over large tracts of landscape (Crutchley and Crow 2010). On the South Downs, Sussex a LiDAR survey in a largely wooded landscape has revealed extensive early field systems with some trackways running through them north to south at right angles to the ridgeway (Manley 2016). Some of the fields are clearly pre-Roman because they are cut across by the early Roman road Stane Street. Other South Downs routes in the Brighton and Worthing area run up the crest of spurs at right angles to the escarpment and these can be shown to be of at least Iron Age origin (Bell 2020). In Sussex prominent hollow ways can be seen descending the escarpment and running north of the escarpment into the Weald where they have been mapped and investigated by Boardman (2013). Some are so deeply incised that they have created alternative lines of drainage and sediment transport, thus highlighting the geomorphic as well as cultural significance of these routes.

Hollow ways are also increasingly recognised in mainland Europe. In Denmark LiDAR has documented pronounced hollow ways where routes marked by barrow alignments descend to river crossing places, for instance at Kilen, Jutland (Bang 2013). On Zealand at Broskov multiple hollow ways bounded by lynchetted fields converge on a stone road of the third century AD which crosses a river valley (Kunwald 1962; Nielsen 2010). Many hollow ways are undated and it is necessary to identify ways in which these key landscape features can, where they are associated with fields, be given a more secure chronology.

\subsection{Methods for investigating trackways in agricultural landscapes}

On slopes the boundaries of early fields are often marked by lynchets, the product of erosion within fields (Bowen 1961; Figure 1). Processes causing soil disturbance on a slope will lead to downslope movement, particularly in unvegetated arable landscapes. Sediment movement is the result of gravity, the action of the plough, rainsplash and runoff during high rainfall events (Bell and Boardman 1992). On the upslope edge of fields erosion occurs where, as soils thin, the plough cuts into bedrock creating a more level bench, known as a negative lynchet. At the downslope edge of a field soil eroded from the field accumulates to form a prominent level bench, the positive lynchet. Positive lynchets are formed of colluvium, an unsorted heterogeneous sediment with scattered stones and often artefacts including pottery. Trackways are often flanked by positive lynchets upslope and negative lynchets downslope; these are double lynchet trackways. Bell (2020, 177-183) provides a more detailed treatment of the range of relationships between fields and trackways, for instance, some trackways run along earlier lynchet terraces and are clearly later. This paper is concerned with a specific case, which field observation suggests is common, where a positive lynchet runs for some distance (ie spanning several early fields) along the uphill side of a trackway. The argument is that the trackways is likely to be contemporary with, or earlier than, the lynchet. Field observation also shows that deeply incised hollow ways, whilst mainly produced by traffic and runoff along their axis, are frequently composite features enhanced by colluvial lynchet accumulations from fields on their uphill side (Figure 1). Such cases are readily identified in the field by a more level bench interrupting the natural slope. This is often present where other traces of former cultivation have been largely obliterated by later cultivation. 
Figure 1. Isometric diagram showing some typical relationships between colluvial deposits, lynchets,

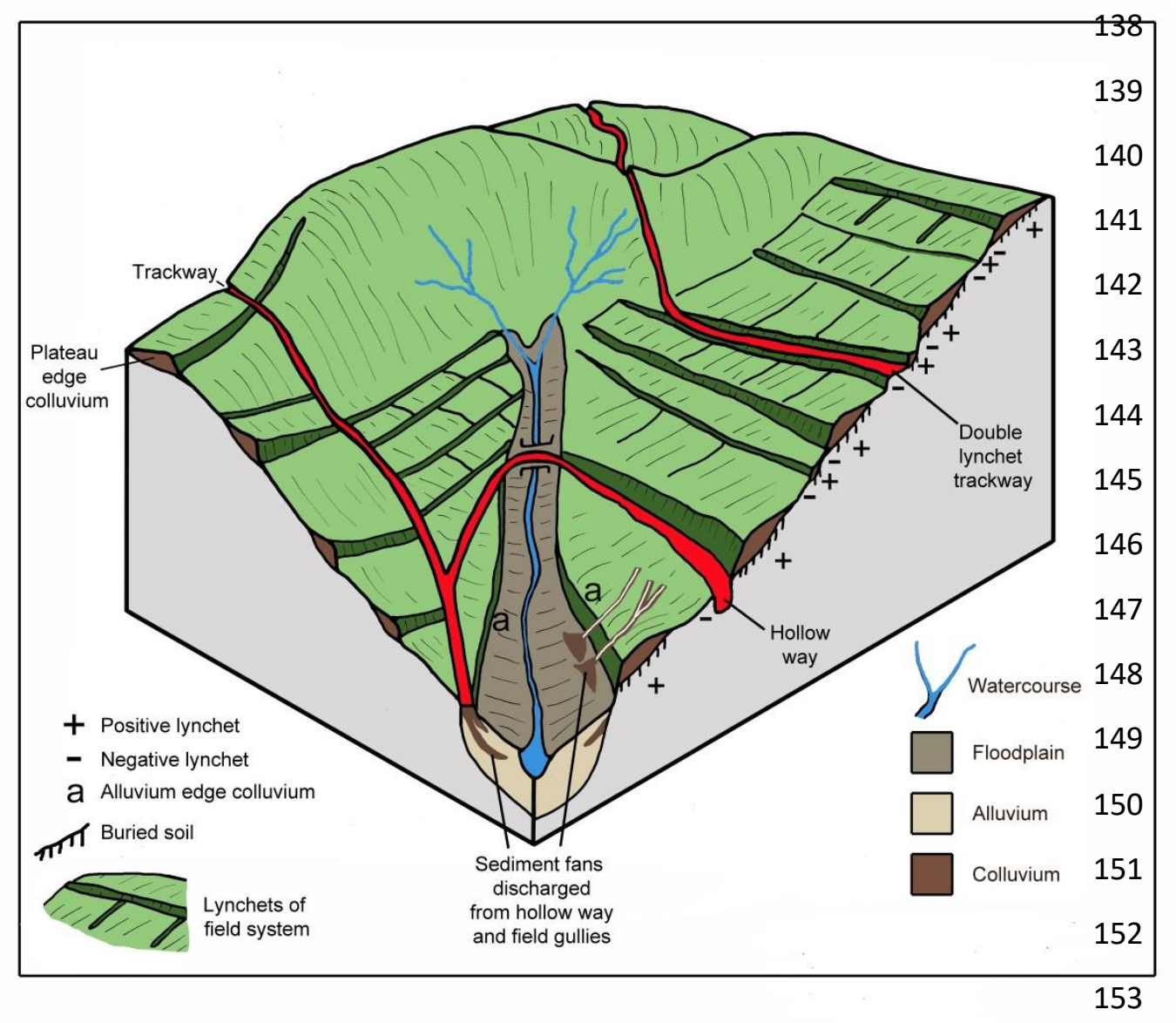

154

Beyond individual fields colluvial deposits also accumulate in dry valleys where there is no running water to remove sediment eroded from the adjacent slopes. Such deposits are particularly prevalent on free-draining substrates such as chalk and limestone but stored sediment accumulations are also found much more widely. They accumulate in situations where topographic factors create long term boundaries to cultivation, such as flood plain edges (alluvium edge colluvium), and where the edge of cultivation on a plateau adjoins steeper downslopes (plateau edge colluvium). All these contexts are relevant because they are equally amenable to the approach to dating proposed here.

\subsection{A multi-method approach to dating colluvium}

Field systems have often been dated by field walking to obtain pottery or other datable artefacts. Experience shows, however, that surface collection often provides evidence only for the latest phase of cultivation, earlier phases being more deeply buried within colluvial sequences, and prehistoric sherds often surviving less well. There are well-documented cases where excavation and recording of the position of large numbers of artefacts within a colluvial sequence, for instance within a lynchet at Bishopstone, Sussex, has produced an apparently reliable chronology, with most pottery stratified in date sequence and apparently providing evidence of the period over which the colluvium built up (Bell 1977, 1983; Allen 1992), as further demonstrated by least-squares mathematical analysis of artefact distributions in the Bishopstone lynchet (Allen 1982). However, there are uncertainties concerning the origin of the artefacts: some may also have been eroded from features and thus have been reworked; some sequences yield few, or no, artefacts; and some investigators have even dismissed colluvium as a reworked deposit of little scientific interest. Furthermore, recording sufficient artefacts to provide a reliable chronology is costly of time and 
resources. We have overcome these problems by developing a more robust multi-method approach to dating colluvium, which, in appropriate circumstances, can also be used to date trackways bounded by lynchets, using optically stimulated luminescence (OSL), molluscs and uranium series dating.

OSL dating is a well-developed methodology applied to Pleistocene and Holocene minerogenic sediments (Duller 2008; Rhodes 2011). It relies on the exposure of mineral grains, chiefly quartz, to light at the time of deposition. In dating colluvium the principal consideration is the compatibility of the datable event and timing of emplacement, since slope processes could limit exposure of minerals to sunlight between initial deposition and downhill reworking (Fuchs and Lang 2009). It is possible to identify 'well-bleached' components within a sample by inter-grain analysis, but the presence of sand grains is a prerequisite for such measurements. There are few precedents in the UK of dating trackways by OSL. One successful example has been at Sharpstone, Shropshire concerning colluvial lenses interleaved with road metalling which demonstrated that the road, originally thought to be of Roman origin, originated at least as early as the Iron Age (Malim and Hayes 2011).

Land Mollusca are widely used to provide evidence of past environments (Evans 1972; Allen 2017). They may also contribute evidence of dating if other studies, with robust chronologies, suggest dates at which certain taxa were introduced, or became extinct (Davies 2010). Inevitably there is some risk of circular arguments here, extinctions and introductions may be local and dates are subject to revision as more robust chronologies are developed (eg Walker 2018).

Direct uranium series dating (Ivanovich and Harmon 1992) of the mollusc shells themselves offers a further approach to this problem. Uncertainties relating to reworking can be addressed to some extent by factoring the condition of the shells and considering the overall molluscan sequence of which they form part. More problematic is establishing whether, in the context in question, mollusc shell can be considered a closed system for uranium series. In some cases researchers have obtained dates which are comparable to those indicated by other sources of dating (Magnani et al 2007; McLaren and Rowe 1996; Hellstrom and Pickering 2015). The comparative nature of the case study below is a contribution to the evaluation of this technique. Another potential dating method, not applied here, is radiocarbon, although the problems of reworking mean that is only generally applicable where discrete burning, or depositional contexts are stratigraphically related to colluvial sediments or trackways, or when it is applied to specific mollusc taxa which have been shown not to accumulate old carbon (Douka 2017). Each of the dating techniques involve uncertainties but the multi-method approach adopted minimises these.

\subsection{Theory and calculation}

The overall theory is that field lynchet banks aligned on trackways as shown diagrammatically on Figure 1 can be used to date them. The uncertainties inherent in the dating of reworked sediments of colluvial derivation can be substantially reduced by using a range of appropriate dating methods in a comparative way. Uranium series and OSL dates have been further refined by the application of Bayesian statistical approach to the stratigraphic sequence of dates using BACONv2.3.3 run in R to create an age depth model (Blaauw and Christen 2011). Weighted mean modelled dates are then calculated for sample depth ranges and thus modelled dates established for sedimentary and molluscan changes. Additionally, the comparative approach takes account of dating evidence provided by artefacts, such as pottery, and biological evidence, in this case the regionally attested introduction dates of molluscan taxa.

\section{Case study from Lyminge, Kent}

To test this approach we selected a case study of a cross-topographic hollow way, a class of early routeway which is widely represented in Britain and elsewhere. This class has particular cultural 
Figure 2. The Lyminge area, (a) Kent, UK showing (b and $c$ ) the relationship between routeways, early fields, the Chalk escarpment and archaeological features including (d) the lynchet sampled in section (graphic J. Foster).

significance because it connects contrasting environmental zones (Bell 2020) and has not previously been reliably dated. The location was Lyminge, Kent (Figure 2), on the dip slope of the North Downs, a major Anglo-Saxon high status centre of the fifth to seventh centuries AD which was succeeded by a monastery in the seventh century AD (Thomas 2013, 2017; Thomas et al 2016). This site lies 3km 
east of the escarpment of the North Downs, along which runs the long distance footpath, the North Downs Way, for which some have claimed prehistoric origins (eg Ordnance Survey 1975). A parallel route, the Pilgrims Way here runs along the foot of the escarpment. Maslin (2017) has investigated the environmental history of the Lyminge landscape.

A routeway Woodland Road, deeply incised in places as a hollow way (Figure 3a) runs west from Lyminge up to and crossing the Roman road Stone Street which connected Canterbury to the shore fort at Lympne (Margary 1955), the continuation of the Woodland Road route then descends the escarpment to the Weald. At Born Meadow, Woodland Road (UK NGR TR14854130), the collapse of a retaining wall revealed a substantial flanking bank of colluvium $3 \mathrm{~m}$ thick (Figure $3 \mathrm{~b}$ ). The hollow way was incised $c 1-1.5 \mathrm{~m}$ into the chalk bedrock but at this particular spot the greater part of the topographic feature was made up of a substantial lynchet bank along the routeway's uphill edge. On the south edge the track was not incised at all, but the slope below was scarped away by a negative lynchet. What $250 \mathrm{~m}$ west is a deeply incised hollow way was, at this point, a double lynchet trackway (Figure 1). By dating the lynchet we have a way of establishing the age of the routeway, which must either be earlier than the fields which flank it, or contemporary. Subsequent to the scientific dating reported here, on what turned out to be Phase 2 of the lynchet, further weathering of the section revealed that the dated sequence was underlain to the east by a Phase 1 lynchet
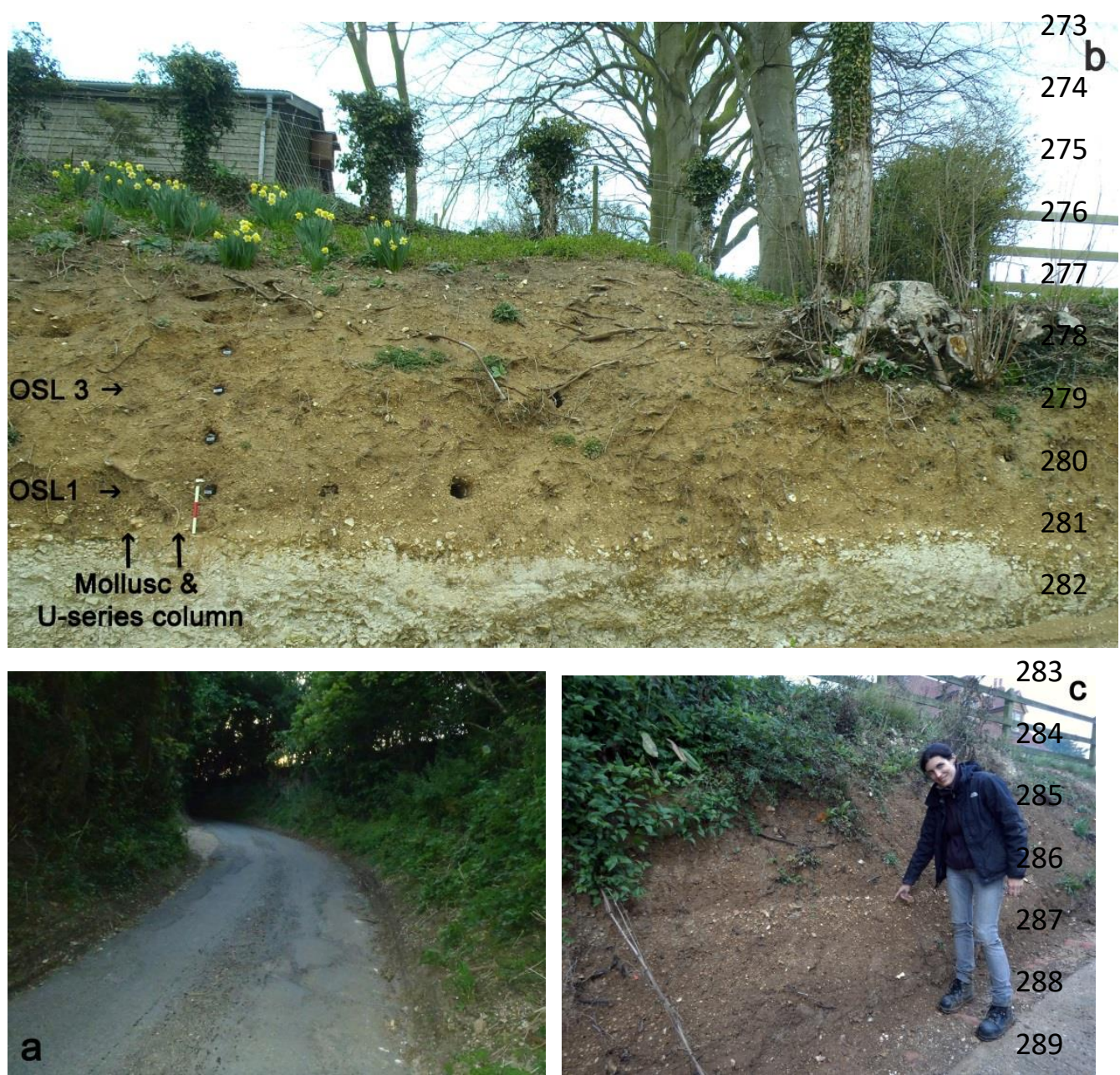

Figure 3. (a) Woodland Road, Lyminge hollow way west of sampled section; (b) sampled lynchet section showing position of OSL and mollusc samples, scale $30 \mathrm{~cm}$; (c) the Phase 1 lynchet to the right of (b) (photos M. Bell). 
capped by an earthworm-sorted buried soil (Figure 3c).

Field investigation showed that these lynchets were part of a more extensive field system which was well preserved in places along the north side of Woodland Road (Figure $2 b$ and $c$ ). A levelled profile of the lynchets was made using a combination of dumpy level and differential GPS. This profile shows the relationship between the lynchets and the sampled sequence, it also shows a sketch section where the routeway becomes a hollow way $250 \mathrm{~m}$ west (Figure $2 \mathrm{~d}$ ). A key observation is that the positive lynchet continues for up to $500 \mathrm{~m}$ on the north side of Woodland Road from the double lynchet trackway to the hollow way. From this it may be inferred that the field edge is a longstanding feature rather than the routeway being fitted around existing field boundaries. Elsewhere in the surroundings traces of early fields have been largely levelled by cultivation and only survive as traces mapped in Figure $2 \mathrm{~b}$ and $\mathrm{c}$ from air photographs and LiDAR.

The first dating method used artefacts. Five pieces of pottery were found in the Phase 1 lynchet (Figure 3c). These have been examined by Keith Parfitt and colleagues from the Canterbury Archaeological Trust, specialists in the pottery of the area. They identify three sherds, two from the body of the early phase lynchet, as flint-tempered sherds of the Late Bronze Age or Iron Age, pre 50 $B C$. Two of the sherds from the stone accumulation horizon on the surface of the Phase 1 lynchet are grog-tempered sherds of late Iron Age 'Belgic' type c 50 BC to AD 80, with another Late Bronze Age or Iron Age sherd from the same horizon. The Phase 2 lynchet produced no datable artefacts apart from flint flakes.

The second dating method concerned two samples which were taken for analysis of optically stimulated luminescence (OSL). Sample 1 was from the base of the Phase 2 lynchet at $1.93 \mathrm{~m}$ depth (Figure $3 b)$. Sample 3 was from the middle of the Phase 2 lynchet at $1.18 \mathrm{~m}$ depth. Dose rate $\left(D_{r}\right)$ values and an assessment of $U$ disequilibrium were developed from ex situ Ge gamma spectrometry. Equivalent dose $\left(D_{e}\right)$ values were obtained from multi-grain aliquots of fine silt quartz. The results are outlined in Table 1; the achieved date is expressed in years before the date of analysis 2015 . Details on sampling, laboratory preparation and measurements are in Appendix A. Measurement

Table 1. Optically stimulated luminescence dates for Woodland Road, Lyminge

\begin{tabular}{|c|c|c|c|c|c|c|c|}
\hline $\begin{array}{l}\text { Field } \\
\text { Code }\end{array}$ & $\begin{array}{l}\text { Gloucestershire } \\
\text { Lab Code }\end{array}$ & $\begin{array}{l}\text { Depth } \\
\text { (m) }\end{array}$ & ${ }^{226} \mathrm{Ra} /{ }^{238} \mathrm{U}$ & Mean $D_{r}\left(G y \cdot k a^{-1}\right)$ & Mean $D_{e}(G y)$ & Date (AD) & $\begin{array}{c}\text { Modelled } \\
\text { date } \\
\text { range for } \\
\text { depth in } \\
\text { Bacon } \\
\text { [incl. U- } \\
\text { Series] }\end{array}$ \\
\hline OSL 1 & GL15049 & 1.93 & $1.52 \pm 0.33$ & $1.34 \pm 0.06$ & $2.27 \pm 0.09$ & $320 \pm 100$ & $\begin{array}{l}183- \\
394 A D\end{array}$ \\
\hline OSL 3 & GL15050 & 1.18 & $1.09 \pm 0.26$ & $1.18 \pm 0.05$ & $1.43 \pm 0.05$ & $810 \pm 70$ & $\begin{array}{c}\text { 699- } \\
\text { 864AD }\end{array}$ \\
\hline
\end{tabular}

diagnostics showed no significant feldspar contamination and no impact of signal sensitivity changes during the process of acquiring $D_{e}$ values. Signal analysis did not reveal any evidence of partial bleaching, though such tests do not necessarily rule out this effect. The constancy of $D_{r}$ during burial for sample 1 may be influenced by potentially significant (>50\%) Uranium disequilibrium, but the impact on age is likely limited given the comparative contribution of $U$ to mean $D_{r}$ and the relatively short burial period. 
The third analytical method using land molluscs is mainly concerned with the investigation of the local environment, but also contributes indirectly to the question of dating. The sediments were rich in land molluscs and a sequence of 12 samples was taken from $0-2.1 \mathrm{~m}$ depth. Above this the top of the colluvium was disturbed by trees and could not be sampled. It is unfortunate that no mollusc samples were taken from the Phase 1 lynchet, because this was only later revealed following further weathering of the section. The results of mollusc analysis are shown alongside the dating evidence in Figure $4 a$. The detailed molluscan evidence relating to local environmental conditions is outlined in Appendix B. In summary there are three Molluscan Assemblage Zones (MAZ). At the base (MAZ 1) are remnants of a former woodland assemblage in the truncated palaeosol. In MAZ 2 this was replaced by a more restricted fauna of open conditions, which, considering that the sediments themselves indicate slope instability, suggests arable. However, the abundance of Vallonia excentrica and its association with Pupilla muscorum suggests significant episodes of grassland and arable. At the top in MAZ 3 these are accompanied by more shade-loving taxa which may relate in part to the origins of the tree-covered bank along the trackway.

This mollusc sequence makes an indirect contribution to dating the sequence because three of the species present represent later Holocene introductions to the British Isles, the introduction dates for which are known with reasonable confidence from other sites in South East England (Davies 2010). The earliest of these is Monacha cantiana (Figure 4c), first recorded at 1.8-1.9m, and a significant presence in MAZ 2 and 3. This species has been regarded as a late Roman introduction although rare until the Medieval period (Kerney 1970, 1999). The occurrence of a single example of Cornu aspersum at $1.4-1.6 \mathrm{~m}$ is also significant in terms of dating because this species was an early Roman introduction to Britain (Kerney 1999). The third chronologically significant species is Candidula intersecta (Figure $4 \mathrm{~b}$ ) with a single example at $1.4-1.6 \mathrm{~m}$ and a more continuous presence in MAZ 3. There are no certain examples of this species in the British Isles before the medieval period (Kerney 1999; Davies 2010; Walker 2018). 

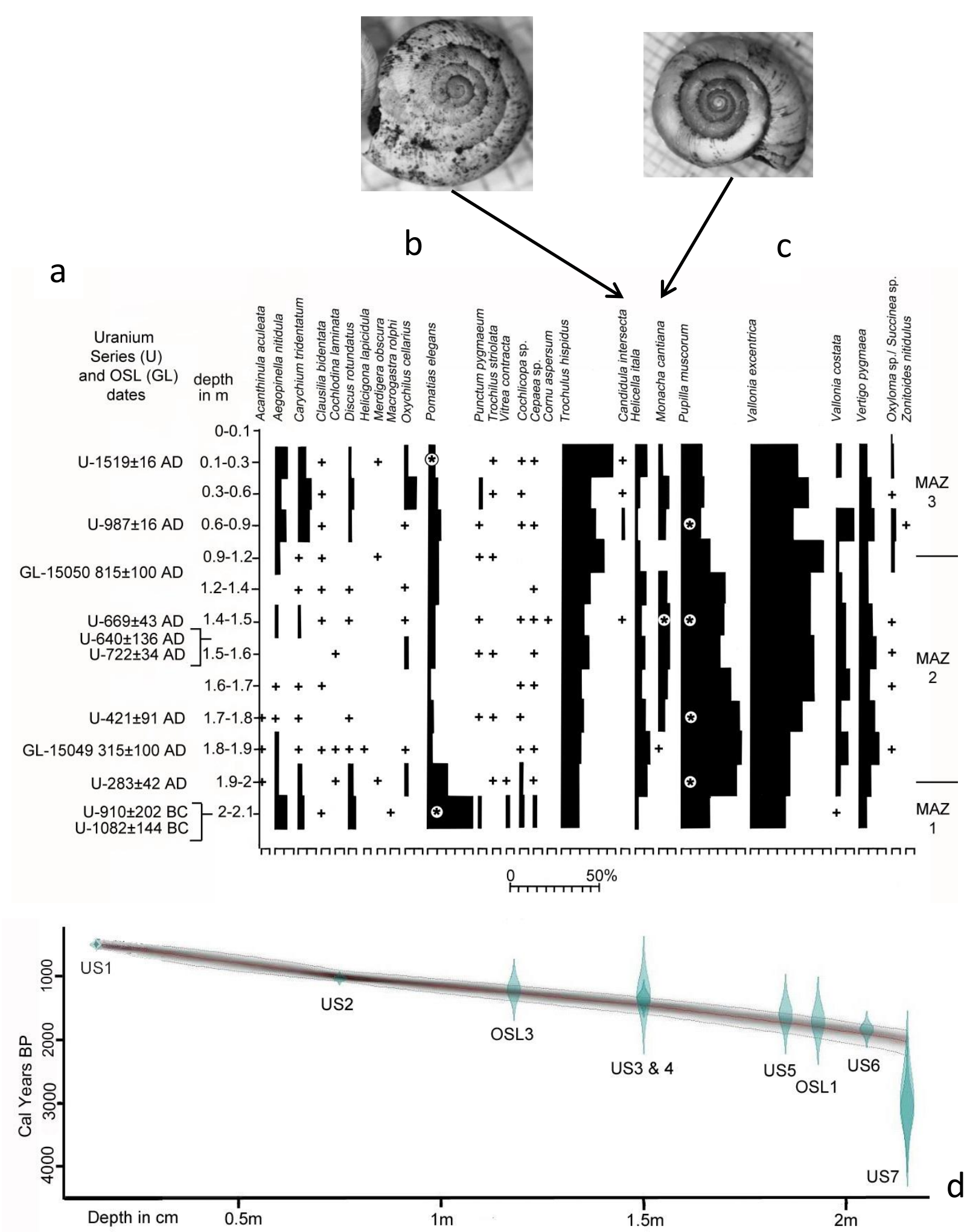

Figure 4. Lyminge, Woodland Road (a) mollusc diagram with the Uranium Series and OSL dates (before 2015) to left. Mollusca samples for U-Series are marked by circles and asterisks, (b) Candidula intersecta and (b) Monacha cantiana, (d) Graph of time / height showing the OSL and U-Series results. 
Table 2. Uranium Series shell dates, Woodland Road Lynchet sequence

\begin{tabular}{|c|c|c|c|c|c|c|c|c|c|c|}
\hline US & $\begin{array}{l}\text { Depth } \\
\text { (m) }\end{array}$ & $\begin{array}{l}\text { Mollusc } \\
\text { species }\end{array}$ & $\begin{array}{l}\text { Uncorrecte } \\
\text { d } \\
\text { U-Th } \\
\text { Age (years) }\end{array}$ & $\begin{array}{l}\text { U-Th } \\
\text { isochron } \\
\text { age } \\
\text { (years) }\end{array}$ & MSWD & $\begin{array}{l}\text { Prob- } \\
\text { ability }\end{array}$ & $\begin{array}{l}\text { Isochron } \\
\text { initial } \\
\left({ }^{234} \mathrm{U} /{ }^{238} \mathrm{U}\right)\end{array}$ & $\begin{array}{l}\text { Calendar } \\
\text { Age } \\
\text { BC/ AD }\end{array}$ & \begin{tabular}{|l|} 
Modelled \\
date range \\
for depth \\
using Bacon
\end{tabular} & $\begin{array}{l}\text { Modelled } \\
\text { weighted } \\
\text { mean date } \\
\text { for depth } \\
\end{array}$ \\
\hline 1 & $0-0.3$ & $\begin{array}{l}\text { Pomatius } \\
\text { elegans } \\
\text { (6 samples) }\end{array}$ & $\begin{array}{l}536 \pm 72 \\
497 \pm 151 \\
556 \pm 131 \\
484 \pm 105 \\
505 \pm 156 \\
473 \pm 68\end{array}$ & $496 \pm 16$ & 0.07 & 1 & $\begin{array}{l}1.347 \pm \\
0.061\end{array}$ & $\begin{array}{l}1519 \pm \\
16 A D\end{array}$ & $\begin{array}{l}1270- \\
1568 A D\end{array}$ & \begin{tabular}{|l|}
$1389-$ \\
$1519-A D$
\end{tabular} \\
\hline 2 & $0.6-0.9$ & $\begin{array}{l}\text { Pupilla } \\
\text { muscorum } \\
\text { (5 samples) }\end{array}$ & $\begin{array}{l}1027 \pm 86 \\
991 \pm 73 \\
971 \pm 155 \\
1050 \pm 111 \\
1040 \pm 76\end{array}$ & $1028 \pm 16$ & 0.77 & 0.6 & $\begin{array}{l}1.314 \pm \\
0.053\end{array}$ & $\begin{array}{l}987 \pm 16 \\
A D\end{array}$ & $\begin{array}{l}845-1248 \\
A D\end{array}$ & $\begin{array}{l}920- \\
1126 \mathrm{AD}\end{array}$ \\
\hline 3 & $1.4-1.6$ & $\begin{array}{l}\text { Pupilla } \\
\text { muscorum } \\
\text { (6 samples) }\end{array}$ & $\begin{array}{l}1371 \pm 46 \\
1356 \pm 60 \\
1259 \pm 37 \\
1345 \pm 97 \\
1397 \pm 36 \\
1358 \pm 39\end{array}$ & $1346 \pm 43$ & 1.3 & 0.25 & $\begin{array}{l}1.324 \pm \\
0.043\end{array}$ & $\begin{array}{l}669 \pm 43 \\
A D\end{array}$ & $446-760 \mathrm{AD}$ & $\begin{array}{l}551-670 \\
A D\end{array}$ \\
\hline 4 & $1.4-1.6$ & $\begin{array}{l}\text { Monacha } \\
\text { cantiana } \\
\text { (2 samples) }\end{array}$ & $\begin{array}{l}1293 \pm 134 \\
1375 \pm 136\end{array}$ & & & & & $\begin{array}{l}722 \pm \\
134 A D \\
640 \pm \\
136 A D\end{array}$ & $446-760 \mathrm{AD}$ & $\begin{array}{l}551- \\
670 A D\end{array}$ \\
\hline 5 & $1.8-1.9$ & $\begin{array}{l}\text { Pupilla } \\
\text { muscorum } \\
\text { (7 samples) }\end{array}$ & $\begin{array}{l}1539 \pm 49 \\
1506 \pm 95 \\
1661 \pm 102 \\
1601 \pm 50 \\
1581 \pm 65 \\
1666 \pm 45 \\
1494 \pm 100\end{array}$ & $1594 \pm 91$ & 0.76 & 0.66 & $\begin{array}{l}1.346 \pm \\
0.056\end{array}$ & $\begin{array}{l}421 \pm 91 \\
A D\end{array}$ & 205-511AD & $\begin{array}{l}316- \\
396 A D\end{array}$ \\
\hline 6 & $1.9-2$ & $\begin{array}{l}\text { Pupilla } \\
\text { Muscorum } \\
\text { (5 samples) }\end{array}$ & $\begin{array}{l}1779 \pm 43 \\
2134 \pm 83 \\
1700 \pm 114 \\
1844 \pm 122 \\
1871 \pm 51\end{array}$ & $1832 \pm 42$ & 2.3 & 0.032 & $\begin{array}{l}1.34 \pm \\
0.15\end{array}$ & $\begin{array}{l}283 \pm 42 \\
A D\end{array}$ & $2-332 A D$ & $\begin{array}{l}122- \\
222 A D\end{array}$ \\
\hline 7 & $2-2.1$ & $\begin{array}{l}\text { Pomatius } \\
\text { elegans } \\
\text { (2 samples) }\end{array}$ & $\begin{array}{l}3097 \pm 144 \\
2925 \pm 202\end{array}$ & & & & & $\begin{array}{l}1082 \pm \\
144 \mathrm{BC} \\
910 \pm \\
202 \mathrm{BC}\end{array}$ & $938-1112 \mathrm{BC}$ & 1061BC \\
\hline
\end{tabular}

367 The fourth dating method was uranium series dating. Samples of molluscs were selected from 7 368 sample horizons (Figure 4a) as outlined in Table 2. Single taxa were used for each sample. Those selected were robust taxa providing sufficient material for dating without signs of erosion or diagenesis. The shells were ultrasonically cleaned. A detailed description of the methodology and results is presented in Appendix C. Between 2 and 7 shells of the same species were analysed from each sample and, as Table 2 shows, a good level of reproducibility was achieved within a sample, which is notable given the colluvial origins of the sediment in question. From the lowest horizon (2.0-2.1m) Pomatius elegans was analysed and a modelled weighted mean date of $1061 \mathrm{BC}$ was obtained. This species tends to be residual in rendzina subsoils and this may provide some indication of the date of the former woodland. There was a clear hiatus in the sequence above this basal horizon which has been factored into the age depth model in Figure $4 \mathrm{~d}$. From the main body of the lynchet the species selected was Pupilla muscorum and these provided a consistent sequence of dates through the sediment sequence as Table 2 shows. The lowest of these from 1.9-2.0m provided a modelled weighted mean date of 122-222 AD. The remainder of the Pupilla samples suggest steady accumulation to the upper Pupilla sample dated with a modelled weighted mean date of 920-1126 AD. From the horizon between 1.4-1.6m 2 samples of Monacha cantiana produced a modelled weighted mean date of 551-670 AD; the unmodelled dates are close to Pupilla dates from the same sample (Table 2). The upper sample dated comprised 6 shells of Pomatius elegans which 
again produced consistent results with a modelled weighted mean date of 1389-1519 AD. This dispels previous concern that this taxa might represent residual reworked material from earlier subsoil for which prehistoric dates had been obtained.

\section{Discussion: Comparative chronologies}

Taken individually each of the dating techniques employed in this case study could be open to question. Artefacts found in colluvium may be reworked; samples dated by OSL may be from earlier aggregates, or grains insufficiently exposed to light; mollusc species may have been introduced earlier, or later, than the currently accepted dates; and uranium series may not represent a closed system, or have involved reworked or intrusive samples. However, these techniques have not been applied in isolation and together they provide a robust and consistent chronology for the colluvial sequence. It is particularly notable that the OSL dates and U-series dates closely follow the same time depth curve, demonstrating their consistency (Figure 4d). Even the lowest OSL sample, which was noted as having potentially significant $U$ disequilibrium, lies on a consistent line between the $U$ series dates above and below. Such a consistent set of results demonstrates the applicability of both OSL and U-Series dating methods to colluvial sediment sequences.

This chronology suggests that an earlier woodland phase may have been cleared $c 1000 \mathrm{BC}$. The earliest phase of the lynchet (which has not been proved to lie on the edge of the road, but probably did so) was established in the late Bronze Age or Early Iron Age following clearance and was followed by a stabilisation soil of the late Iron Age. As noted there is no molluscan and other dating evidence, apart from artefacts from the Phase 1 lynchet. The base of the Phase 2 lynchet is Romano-British as both uranium series and OSL confirm. Also notable is that the lynchet accumulated without any obvious interruption from Romano-British times into the early Saxon period and through into the Medieval period. The occurrence of shade loving taxa in the molluscan sequence MAZ-3 suggests the wooded bank along the trackway and lynchet was in existence from about 800 AD following the upper OSL date. Given the significance of Lyminge as an early medieval administrative centre it is of interest that this area, $1.5 \mathrm{~km}$ west of the Anglo-Saxon settlement, was, from the scale and time depth of slope instability, well-used arable with alternating pasture from the early Romano-British period. This continued through the period of the Anglo-Saxon settlement and succeeding monastic phase, and through the medieval period until at least a modelled weighted mean date of 1270-1568 AD. The colluvium lacked artefacts so the field may not have been manured and was perhaps outfield subject to regular pastoral rotation as the molluscs seem to suggest. We should note that this date is the top of the sampled sequence, not the top of the lynchet which was disturbed by trees and not sampled.

\section{Conclusions}

Much has been written about prehistoric and early historic field systems. Less is understood about the landscape-scale patterns created by trackways. The approach adopted here has been to investigate trackways and fields in a connected way as equally significant parts of agricultural landscapes. The working hypothesis, that the dates of routeways, such as hollow ways, can be established by dating flanking lynchet banks, with which they are either contemporary or predate, has been supported by the close correspondence between comparative dating techniques in the case study. This trackway has been shown by a combination of Uranium Series, OSL and mollusc analysis to be of at least Romano-British origin, significantly predating the major Anglo-Saxon centre to which it leads founded in the fifth century AD. The pottery in the Phase 1 lynchet strongly suggests earlier Late Bronze Age or Iron Age origins. It is of course possible that the route predated the flanking fields. The continuity of cultivation implied by this sequence contributes to an emerging picture of continuity of landscape organisation across the transition from Romano-British to medieval which is apparent from research on field system organisation in other areas (Williamson 2008; Rippon et al 2015). Dating precision could have been refined by closer molluscan sampling and 
U-Series dating and more OSL dates. Such an approach would be justified in future where key issues of cultural continuity and change are under investigation, such as from Roman to early medieval. This study has indicated the early origins of a cross topographic route from downland to Weald. This route is not straight with some bends and it is unclear to what extent this represents a major communication axis; it may well be one of a series of routes whereby settlements in the Lyminge area accessed Wealden resources and vice versa. The main significance of this study is in demonstrating a means of dating past routeways.

A similar dating strategy could be applied to related contexts. Erosion of deeply incised hollow ways will have produced significant volumes of sediment deposited, for instance in depositional fans, in sediment traps such as flood plain margins (Figure 1). Dating these sediments provides a potentially more direct way of establishing when erosion of a hollow way occurred; this has yet to be tested. This multi-method approach is also applicable to colluvial sediments in other contexts such as field banks, unrelated to routes, and dry valley fills. Where the sediment involved is of field derivation, albeit in some cases transported by runoff down incised hollow ways (Boardman 2013), dating can make a significant contribution to understanding the history of soil erosion which is central to evaluation of long-term soil sustainability.

\section{Acknowledgements}

Steve and Jo Craig for permission to sample at Lyminge; Dr Gabor Thomas, director of the Lyminge project; Dr Alex Knox for field assistance; Dr Chris Speed and Dr Tom Walker for laboratory assistance. The original mollusc analysis was assisted by our Archaeological Science class of 2015. Stimulating discussion with Dr John Boardman on soil erosion and hollow ways and advice from Dr Duncan Garrow and Keith Parfitt are acknowledged as are helpful recommendations from reviewers and editors.

Funding: University of Reading, UK

\section{References}

Allen, L. 1982 A study of the chronological development of the Bishopstone lynchet by least-squares analysis of the distribution of datable artefacts. Sussex Archaeological Col. 120, 207-209.

Allen, M.J. 1992 Products of erosion and the prehistoric land-use of the Wessex Chalk. In: Bell, M. and Boardman, J. (ed), Past and Present Soil Erosion. Oxford: Oxbow Monograph 22, 37-52.

Allen, M.J. 2017 Molluscs in Archaeology: Methods, approaches and applications. Oxford: Oxbow.

Anderson, R. 2005 An annotated list of the non-marine Mollusca of Britain and Ireland. J. Conchology 38(4), 341-353.

Bakker, J.A. 1976 On the possibility of reconstructing roads from the TRB period, Berichten van de Rijksdienst voor het Oudheidkundig Bodemonderzoek Jaargang 26, 63-91.

Bakker, J.A. 1991 Prehistoric long-distance roads in North-West Europe. In: Lichardus, J. (ed), Die Kupferzeit als historische Epoche. Bonn: R. Habelt, 502-28.

Bang, J. 2013 The route to a history of the cultural landscape: a Danish record of prehistoric and historic roads, tracks and related structures. In: Bergerbrant, S. and Sabatini, S. (ed), Counterpoint: Essays in archaeology and heritage studies in honour of Professor Kristian Kristiansen. Oxford: BAR IS 2508, 703-15.

Bell, M. 1977 Excavations at Bishopstone, Sussex Archaeological Col, 115.

Bell, M. 1983 Valley sediments as evidence of prehistoric land-use on the South Downs, Proc. Prehist. Soc. 49, 119-150.

Bell, M. 2020 Making One's Way in the World: the footprints and trackways of prehistoric people. Oxford: Oxbow.

Bell, M. and Boardman, J. 1992 Past and Present Soil Erosion. Oxford: Oxbow Monograph 22. 
Bell, M. and Leary, J. 2020 Pathways to past ways: a positive approach to routeways and mobility. Antiquity.

Blaauw, M. and Christen, J.A. 2011 Flexible palaeoclimatic age-depth models using an autoregressive gamma process. Bayesian Anal. 6.3, 457-474.

Boardman, J. 2013 The hydrological role of 'sunken lanes' with respect to sediment mobilization and delivery to watercourses with particular reference to West Sussex, southern England, J. Soils \& Sediments 13, 1636-1644.

Booth, P., Champion, T., Foreman, S., Garwood, P., Glass, H., Munby, J. and Reynolds, A. 2011 On Track: The Archaeology of High Speed I Section I in Kent. Oxford: Oxford Wessex Archaeology.

Bowen, H.C. 1961 Ancient Fields. Wakefield: S.R. Publishers Ltd.

Brandon, P. 1974 The Sussex Landscape. London: Hodder and Stoughton.

Carter, S.P. 1990 The stratification and taphonomy of shells in calcareous soils: implications for land snail analysis in archaeology. J. Archaeol. Sci. 17, 495-507.

Crutchley, S. and Crow, P. 2010 The Light Fantastic: using airborne LiDAR in archaeological survey. Swindon: English Heritage.

Cummings, V. and Johnston, R. 2007 Prehistoric Journeys. Oxford: Oxbow.

Curwen, E. and Curwen, E.C. 1923 Sussex lynchets and their associated field ways, Sussex Archaeol. Coll. 64, 1-65.

Davies, P. 2010 Land and Freshwater molluscs. In: O'Connor, T. and Sykes, N. (ed), Extinctions and Invasions: A social history of British fauna. Oxford: Windgather Press, 175-89.

Douka, K. 2017 Radiocarbon dating of marine and terrestrial shell. In: Allen, M.J. (ed), Molluscs in Archaeology: Methods, approaches and applications. Oxford: Oxbow, 381-399.

Duller, G.A.T. 2008 Luminescence Dating. Swindon: English Heritage.

Evans, J. 1972 Land Snails in Archaeology. London: Seminar Press.

Everitt, A. 1986 Continuity and Colonization: the evaluation of Kentish settlement. Leicester: Leicester University Press.

Fowler, P.J. 1998 Moving through the landscape. In Everson, P. and Williamson, T (ed) The Archaeology of landscape: studies presented to Christopher Taylor. Manchester: Manchester University Press, 25-41.

Fowler, P. 2000 Landscape Plotted and Pieced: landscape history and local archaeology in Fyfield and Overton, Wiltshire. London: The Society of Antiquaries.

Fox, C. 1923 The Archaeology of the Cambridge Region. Cambridge: Cambridge University Press.

Fuchs, M. and Lang, A. 2009 Luminescence dating of hillslope deposits - a review, Geomorphology $109,17-26$.

Harrison, S. 2003 The Icknield Way: some queries, Archaeol. J. 160, 1-22.

Hellstrom, J. and Pickering, R. 2015 Recent advances and future prospects of the U-Th and U-Pb chronometers applicable to archaeology, J. Archaeol. Sci. 56, 32-40.

Hindle, B.P. 1993 Roads, Tracks and their Interpretation. London: Batsford.

Ingold, T. 2011 Being Alive: essays on movement, knowledge and description. Abingdon: Routledge.

Ivanovich, M. and Harmon, R. S. (Eds.) (1992) Uranium Series Disequilibrium Applications to Enviromental Problems, Oxford: Oxford University Press.

Kerney, M.P. 1970 The British distribution of Monacha cantiana (Montagu) and Monacha cartusiana (Muller). J. Conchology, London, 27, 145-148.

Kerney, M.P. 1999 Atlas of Land and Freshwater Molluscs of Britain and Ireland. Colchester: Harley Books.

Klassen, L. 2014 Along the Road: Aspects of causewayed enclosures in South Scandinavia and beyond. Aarhus: Aarhus University Press.

Kunwald, G. 1962 Broskovvejene, Nationalmuseets arbejdsmark 149-67.

Laland, K.N. and O'Brien, M.J. 2010 Niche construction theory and archaeology, J Archaeol. Method \& Theory 17, 303-22.

Leary, J. 2014 Past Mobilities. Farnham: Ashgate. 
Leary, J. and Kador, T. 2016 Moving on in Neolithic Studies. Oxford: Oxbow. MacFarlane, R. 2012 The Old Ways: a journey on foot. London: Penguin.

Magnani, G., Bartolomei, P., Cavulli, F., Esposito, M., Marino, E.C., Neri, M., Rizzo, A., Scaruffi, S. and Tosi, M. 2007 U-series and radiocarbon dates on mollusc shells from the uppermost layer of the archaeological site of KHB-1, J. of Archaeol. Sci. 34, 749-55.

Malim, T. and Hayes, L. 2010 An engineered Iron Age road, associated Roman use (Margary Route 64) and Bronze Age activity recorded at Sharpstone Hill, 2009, Trans. Shropshire Arch. and Hist. Soc. 85, 7-80.

Manley, J. (ed) 2016 Secrets of the High Woods: revealing hidden landscapes. Midhurst: South Downs National Park Authority.

Margary, I.D. 1955 Roman Roads in Britain. London: Phoenix House.

Maslin, S. 2017 The Landscape and Ecology of the Anglo-Saxon Conversion: a multiproxy environmental and geoarchaeological contextualisation of the high-status settlement at Lyminge, Kent. Unpublished PhD thesis, University of Reading.

McLaren, S.J. and Rowe, P.J. 1996 The reliability of U-series mollusc dating from the western Mediterranean Basin, Quaternary Sci. Rev. 15, 709-17.

Miles, D., Palmer, S., Lock, G., Gosden, C. and Cromarty, A.M. 2003 Uffington White Horse and its Landscape. Oxford: Oxford Archaeology.

Nielsen, V. 2010 Oldtidsagre i Danmark: Sjælland, Møn og Lolland-Falster. Moesgård: Jysk Arkæologisk Selskab.

Oldling-Smee, F.J., Laland, K.N. and Feldman, M.W. 2003 Niche construction, American Naturalist $147,641-8$.

Ordnance Survey 1975 Map of Southern Britain in The Iron Age. Southampton: Ordnance Survey.

Oosthuizen, S. 2013 Tradition and transformation in Anglo-Saxon England: archaeology, common rights and landscape. London: Bloomsbury Academic.

Preston, P.R. and Schorle, K. 2013 Mobility and Change in Prehistory and Classical Antiquity. Oxford: BAR IS 2534.

Pryor, F 2001 The Flag Fen Basin: archaeology and environment of a Fenland landscape. Swindon: English Heritage.

Rhodes, E.J. 2011 Optically Stimulated Luminescence dating of sediments over the past 200,000 years, Annual Rev. Earth \& Planetary Sci. 39, 461-88.

Rippon, S., Smart, C. and Pears, B. 2015 The Fields of Britannia. Oxford: Oxford University Press.

Snead, J.E., Erickson, C.L. and Darling, J.A. 2009 Landscapes of Movement: Trails, paths and roads in anthropological perspective. Philadelphia: University of Pennsylvania.

Taylor, C. 1979 Roads and Tracks of Britain. London: Dent.

Thomas, G. 2013 Life before the Minster: the social dynamics of monastic foundation at Anglo-Saxon Lyminge, Antiq. J. 93, 109-45.

Thomas, G, McDonnell, G, Merkel, J, and Marshall P 2016, 'Technology, ritual and Anglo-Saxon agriculture: the biography of a plough coulter from Lyminge, Kent', Antiquity 90 (351), 742-58.

Thomas, G 2017, 'Monasteries and places of power in pre-Viking England: trajectories, relationships and interactions', in Thomas, G and Knox, A (eds) 2017, Early Medieval Monasticism in the North Sea Zone: Recent Research \& New Perspectives, Anglo-Saxon Studies in Archaeology and History 20. Oxford: Oxford University School of Archaeology, 97-116.

Tilley, C. 1994 A Phenomenology of Landscape. Oxford: Berg.

Turner, D.J. 1980 The North Downs trackway, Surrey Archaeol. Coll. 72, 1-13.

Walker, T. 2018 The Gwithian Landscape: Molluscs and archaeology in Cornish sand dunes. Oxford: Archaeopress.

Watkins, A. 1925 (2014 edition) The Old Straight Track. London: Head of Zeus.

Williamson, T. 2008 Co-axial landscapes: time and typography. In: Rainbird, P. (ed), Monuments in the Landscape. Stroud: Tempus, 123-35.

Williamson, T. and Bellamy, L. 1983 Ley Lines in Question. Tadworth: World's Work. 
Yates, D.T. 2007 Land, Power and Prestige: Bronze Age field systems in Southern England. Oxford: Oxbow.

\section{Figures}

Figure 1. Isometric diagram showing some typical relationships between colluvial deposits, lynchets, trackways and hollow ways (graphic J. Foster).

Figure 2. The Lyminge area, (a) Kent, UK showing ( $b$ and c) the relationship between routeways, early fields, the Chalk escarpment and archaeological features including (d) the lynchet sampled in section (graphic J. Foster).

Figure 3. (a) Woodland Road, Lyminge hollow way west of sampled section; (b) sampled lynchet section showing position of OSL and mollusc samples, scale $30 \mathrm{~cm}$; (c) the Phase 1 lynchet to the right of (b) (photos M. Bell).

Figure 4. Lyminge, Woodland Road, (a) mollusc diagram with the Uranium Series and OSL dates (before 2015) to left (modelled dates for the same horizons are in Table 2). Mollusca samples for USeries are marked by circles and asterisks, (b) Candidula intersecta and (c) Monacha cantiana (d) Graph of time depth showing the OSL and U-Series results (graphic J. Foster, S. Black).

\section{Tables}

Table 1. Optically stimulated luminescence dates for Woodland Road, Lyminge, see Appendix A for details (by Philip Toms).

Table 2 Uranium Series shell dates, Woodland Road Lynchet sequence, see Appendix C for details (by Stuart Black).

\section{Supplementary material}

Appendix A. Optically Stimulated luminescence (OSL) dating by Philip Toms

Appendix B. Molluscan sequence from Woodland Road, Lyminge by Martin Bell and Simon Maslin

Appendix C. Uranium Series dating methodology by Stuart Black.

\section{9}

(1)

3

4

5

7


Owing to the optical sensitivity of the time-dependent signal, OSL samples were extracted from sections using opaque tubing. To preclude optical erosion of the datable signal prior to measurement, all samples were opened and prepared under controlled laboratory illumination provided by Encapsulite RB-10 (red) filters.

Samples were flocculated and then subjected to acid and alkaline digestion $\left(10 \% \mathrm{HCl}, 15 \% \mathrm{H}_{2} \mathrm{O}_{2}\right)$ to attain removal of carbonate and organic components respectively. Fine silt sized quartz, along with other mineral grains of varying density and size, was extracted by sedimentation in acetone ( $<15 \mu \mathrm{m}$ in $2 \mathrm{~min} 20 \mathrm{~s},>5 \mu \mathrm{m}$ in 21 mins at $20^{\circ} \mathrm{C}$ ). Feldspars and amorphous silica were then removed from this fraction through acid digestion ( $35 \% \mathrm{H}_{2} \mathrm{SiF}_{6}$ for 2 weeks, Jackson et al., 1976; Berger et al., 1980). Following addition of $10 \% \mathrm{HCl}$ to remove acid soluble fluorides, grains degraded to $<5 \mu \mathrm{m}$ as a result of acid treatment were removed by acetone sedimentation.

Calibration of the OSL signal to generate Equivalent Dose $\left(D_{e}\right)$ values drew on the Single-Aliquot Regenerative-Dose protocol (Murray and Wintle, 2000; 2003) applied to 12 standard $10 \mathrm{~mm}, 1.5 \mathrm{mg}$ multi-grain aliquots of 5-15 $\mu \mathrm{m}$ quartz. Appropriate preheat temperatures were evaluated through Dose Recovery tests. Sensitivity correction was monitored through replicate measurements of low and high regenerative-doses. The significance of any feldspar contamination was quantified using post-IR OSL tests (Duller 2003). The occurrence of partial bleaching was assessed through signal analysis (Bailey et al. 2003). The fine silt nature of the deposits precluded inter-grain $D_{e}$ distribution analysis (Olley et al., 2004). Mean $D_{e}$ values were estimated using the Central Age Model (Galbraith et al. 1999).

Dose rate $\left(D_{r}\right)$ values are based on ex situ Ge gamma spectrometry, Adamiec and Aitken's (1998) conversion factors, attenuation of present moisture content (Zimmerman 1971), current overburden and a geomagnetic latitude of $51^{\circ} \mathrm{N}$ (Prescott and Hutton 1994). The degree of U-Series disequilibrium was assessed by ${ }^{226} \mathrm{Ra} /{ }^{238} \mathrm{U}$ (Olley et al., 1996).

Age estimates are defined by the quotient of $D_{e}$ and $D_{r}$ values and are expressed relative to the year of sampling. Uncertainties in age are quoted at $1 \sigma$ confidence, are based on analytical errors and reflect combined systematic and experimental variability.

\section{References}

Adamiec, G. and Aitken, M.J. 1998 Dose-rate conversion factors: new data. Ancient TL, 16, 37-50.

Bailey, R.M., Singarayer, J.S. , Ward, S. and Stokes, S. 2003 Identification of partial resetting using $D_{e}$ as a function of illumination time. Radiat. Meas., 37, 511-518.

Berger, G.W., Mulhern, P.J. and Huntley, D.J. 1980. Isolation of silt-sized quartz from sediments. Ancient $T L, 11,147-152$.

Duller, G.A.T 2003 Distinguishing quartz and feldspar in single grain luminescence measurements. Radiat. Meas., 37, 161-165.

Galbraith, R. F., Roberts, R. G., Laslett, G. M., Yoshida, H. and Olley, J. M. 1999 Optical dating of single and multiple grains of quartz from Jinmium rock shelter (northern Australia): Part I, Experimental design and statistical models. Archaeometry, 41, 339-364.

Jackson, M.L., Sayin, M. and Clayton, R.N. 1976. Hexafluorosilicic acid regent modification for quartz isolation. Soil Sci. Soc. of America J., 40, 958-960.

Murray, A.S. and Wintle, A.G. 2000 Luminescence dating of quartz using an improved single-aliquot regenerative-dose protocol. Radit. Meas. , 32, 57-73. 
Murray, A.S. and Wintle, A.G. 2003 The single aliquot regenerative dose protocol: potential for improvements in reliability. Radiat. Meas., 37, 377-381.

Olley, J.M., Murray, A.S. and Roberts, R.G. 1996 The effects of disequilibria in the Uranium and Thorium decay chains on burial dose rates in fluvial sediments. Quaternary Sci. Rev., 15, 751-760.

Olley, J.M., Pietsch, T. and Roberts, R.G. 2004 Optical dating of Holocene sediments from a variety of geomorphic settings using single grains of quartz. Geomorphology, 60, 337-358.

Prescott, J.R. and Hutton, J.T. 1994 Cosmic ray contributions to dose rates for luminescence and ESR dating: large depths and long-term time variations. Radiat. Meas., 23, 497-500.

Zimmerman, D. W. 1971 Thermoluminescent dating using fine grains from pottery. Archaeometry, 13, 29-52.

\section{Appendix B Molluscan sequence from Woodland Road Lyminge by Martin Bell and Simon Maslin}

The mollusc samples, mostly $2 \mathrm{~kg}$, were processed using standard procedures (Evans 1972) and hydrogen peroxide to disaggregate clods. The nomenclature follows Anderson (2005). The results are shown in Figure 4a. Three molluscan assemblage zones may be identified: -

MAZ-1 base 2.0-2.1m Pomatius elegans peaks at $25 \%$ at the base and then reduces as do the less abundant Aegopinella nitidula, Carychium tridentatum and Discus rotundatus. These are accompanied by the significant presence of Vallonia costata, Pupilla muscorum and Trochulus hispidus, which subsequently increase upwards.

MAZ-2 1.20-2.0m High numbers of shells but a more restricted range of species dominated by Vallonia excentrica, Pupilla muscorum and Trochulus hispidus, with the consistent significant presence of Vertigo pygmaea, Helicella itala, Monacha cantiana, Vallonia costata and Pomatius elegans.

MAZ-3 0-1.2m Dominated by the same three predominant species as the underlying MAZ but as part of a more diverse assemblage in which 12 species have significant presence.

Mollusc numbers were remarkably high for a mainly colluvial sequence, around 300 at the bottom (MAZ-1) and top (MAZ-3) and 400-600 for the middle part of the sequence (MAZ-2).

As regards the interpretation of this sequence the predominance in the basal unit of Pomatius elegans can be attributed to well-attested over-represention in the stone accumulation horizon at the base of rendzina soils on account of the fact that the robust shell of this species is more resistant to erosion, so that it is often older than some of the other shells with which it is found in subsoils (Carter 1990). Other species, however, which are less resistant to erosion such as Aegopinella nitidula, Carychium tridentatum, Discus rotundatus, Oxychilus cellarius and Punctum pygmaeum are also present in this basal zone and are generally found in shaded woodland environments, so the sequence clearly attests to an earlier woodland phase (Evans 1972). These taxa decline upwards within the basal soil and those indicative of open country increase. We may infer from this that a formally wooded or scrubby landscape had become open, probably grassland, by the time of the truncated palaeosol where the main taxa are Vallonia excentrica, Pupilla muscorum and Trochulus hispidus. These three species characterise the central part of the sequence (MAZ-2) with its more restricted range of species, large numbers of molluscs and as the sediments themselves demonstrate, slope instability resulting in colluviation. Although the three predominant species are typical of colluvium, the abundance of Vallonia excentrica, which Evans (1993) has suggested indicates close-grazed grassland, and the significant presence of Pupilla muscorum, Vertigo pygmaea, Helicella itala and Monacha cantiana also point to grassland. This must be reconciled, however with the slope instability attested by the sediment accumulation. Two possible explanations suggest themselves, firstly, that we are dealing with an arable environment with frequent rotations to reasonably well established pasture. Secondly that the grassland component 
could reflect the local environment of the lynchet itself. The occurrence of Monacha cantiana is of particular note in this regard. Kerney (1999) describes its occurrence on waste ground, typical of roadsides which is exactly the context here. For grassland to be maintained on the lynchet it must have been grazed, suggesting that both explanations are to some extent involved. The latter part of MAZ-2 may be correlated with the mid- Saxon activity during the period of monastic settlement at nearby Lyminge during which zooarchaeological data demonstrate a pronounced and intense economic shift to sheep-goat husbandry (Knapp 2017) which corresponds to the molluscan grazing indicators. A multi-proxy palaeoenvironmental investigation of the stream sequence directly adjacent to the Lyminge settlement also points to an open managed landscape throughout the second half of the first millennium AD (Maslin 2018).

In the upper part of the sequence the proportions of the previously predominant species decline and are accompanied by a return of species indicative of shaded woodland conditions. Three explanations suggest themselves. Firstly, that as soils upslope thinned a greater proportion of shells from the earlier subsoil with woodland taxa were eroded. This is disproved by the uranium series dates which showed that the Pomatius elegans shells had a modelled weighted mean date of 12701568 AD. Furthermore, they were accompanied by other shade-loving species less resistant to erosion. Secondly, it may reflect the colonisation of woodland across the former fields, and there is historical evidence for the development of woodland in the wider area to the north (Maslin 2017). Deciduous woodland is currently present in the area now known as West Wood and recorded as far back as a charter of AD 786 as an extensive region called Buckholt (Beech wood) (Canterbury Christ Church S125: Brooks and Kelly 2013). However, the predominant species are still open country and we must remember that this is not the top of the lynchet but the limit of sampling and colluviation continued after 1270-1568AD. The third and more economical explanation is that the shade-loving taxa in MAZ-3 represent the development of a woodland strip along the lynchet and the side of the trackway which remains in places today.

The occurrence of Oxyloma / Succinea and a single Zonitoides nitidus in MAZ-2 and -3 suggests wet patches, maybe a nearby pond or spring seep, an explanation which is strengthened by the collapse of the wall after heavy rain which originally revealed the section in question.

\section{References}

Anderson, R. 2005 An annotated list of the non-marine Mollusca of Britain and Ireland. J. Conchology 38(4), 341-353.

Brooks, N. and Kelly,S.E. 2013 Charters of Christ Church Canterbury. Oxford: Oxford University Press. Carter, S. 1990 The stratification and taphonomy of shells in calcareous soils: implications for land snail analysis in archaeology, J. Archaeol. Sci. 17, 495-507.

Davies, P. 2010 Land and Freshwater molluscs. In: O'Connor, T. and Sykes, N. (ed), Extinctions and Invasions: A social history of British fauna. Oxford: Windgather Press, 175-89.

Evans, J.G. 1972 Land Snails and Archaeology. London: Seminar Press.

Evans, J.G. 1993 The influence of human communities on the English chalklands from the Mesolithic to the Iron Age: the molluscan evidence. In Chambers, F.M. (ed) Climate change and human impact on the landscape. London: Chapman and Hall, 147-56.

Kerney, M. 1999 Atlas of the Land and Freshwater Molluscs of Britain and Ireland. Colchester: Harley Books.

Knapp, Z. 2017 Changing tastes: farming, feasting and fasting at Lyminge. In Thomas, G., Knox, A. and Hamerow, H. (eds) Early Medieval Monasticism in the North Sea Zone. Anglo-Saxon Studies in Archaeology and History 20. Oxford: Oxbow Books, 135-148.

Maslin, S. 2017 The Landscape and Ecology of the Anglo-Saxon Conversion: a multiproxy environmental and geoarchaeological contextualisation of the high-status settlement at Lyminge, Kent. Unpublished PhD University of Reading. 
Maslin, S. 2018 Anglo-Saxon economy and ecology by a downland stream: a waterlogged sequence from the Anglo-Saxon royal settlement at Lyminge, Kent. Environ. Archaeol. 23.2, 137-151.

\section{Appendix C Uranium-Series dating Methodology by Stuart Black}

Methodological approach: Gamma spectrometry

U-Series dating by gamma spectrometry has been reported previously by Yokoyama and Nguyen (1981), Barton and Stringer (1997), Berzero et al. (1997), Simpson and Grun (1998) and Schwarcz et al (1998). This study was carried out at The University of Reading for 230Th, 238U, 234U, 235U, $226 \mathrm{Ra}, 210 \mathrm{~Pb}$ and $228 \mathrm{Ra}$ measured directly by g-spectrometry using the peaks identified in Table $\mathrm{C}$ on the assumption that the short-lived daughters will be in equilibrium with their parent isotopes. However, diffusion loss of the intermediate daughter 222Rn (between 226Ra and 214Pb) from finegrained material can affect $214 \mathrm{~Pb}$ activities; to overcome this all samples were sealed in airtight plastic bags. Samples were counted on a Harwell Instruments, Broad Energy, BE5030 high purity germanium coaxial photon detector. This detector has an ultra-low background set up (detector and cryostat) with a $0.5 \mathrm{~mm}$ thick carbon-epoxy window and remote detector chamber. Detector specifications were FWHM @ $5.9 \mathrm{keV}=0.45 \mathrm{keV}, \mathrm{FWHM} @ 1.3 \mathrm{MeV}=<1.2 \mathrm{keV}$. To keep self-absorption differences negligible, standard samples were used to calibrate the detectors using a carbonate rock standard. A secondary standard was also made in the form of a disc ( $80 \mathrm{~mm}$ diameter) from the same material to which the detector had been calibrated previously.

The $(230 \mathrm{Th} / 238 \mathrm{U})$ activity ratio was determined from the activities at the $67.7 \mathrm{keV}$ and $63.3 \mathrm{keV} \mathrm{g-}$ ray peaks. In addition, the activity of the (226Ra(214Pb)/230Th), using the 295,352 and $67.7 \mathrm{keV} \mathrm{g}$ rays, and the (226Ra $(214 \mathrm{Bi}) / 238 \mathrm{U}(234 \mathrm{mPa}))$ ratios using the 609 and $1764 \mathrm{keV} \mathrm{g}$-rays for $214 \mathrm{Bi}$ and $1001 \mathrm{keV} g$-ray for $234 \mathrm{mPa}$ were also determined.

Samples were counted for approximately 2-10 days each in order to reduce the uncertainties by accumulating a large number of counts in each analyte peak. Most analyte peaks were $>10,000$ net counts (i.e. $<1 \%$ uncertainty). External reproducibility was checked using international standards.

\section{Mass Spectrometry}

Small sub-samples (100-500 mg) were also taken from the carbonates for destructive analysis for determination of the $234 \mathrm{U} / 238 \mathrm{U}, 235 \mathrm{U} / 238 \mathrm{U}$ and $230 \mathrm{Th} / 232 \mathrm{Th}$ ratios. These were undertaken using a Thermo-fisher iCAPQ Inductively Coupled Plasma Mass Spectrometer. The mass ratio of the $234 / 238$ is low $(<1 \%)$ and $230 / 232$ very low $(<0.1 \%)$ but the counts were increased by running the mass spectrometer in isotope ratio mode using 10 replicate analyses, an increased dwell time (100 $\mathrm{ms}$ ) together with an average of 45 passes per replicate sample for $234 / 238$ and increased replicates for $230 / 232$. This brought the uncertainty of the ratios to within a tolerable level $(<1.5 \%$ for $234 / 238$ and $<2 \%$ for $230 / 232$ ). External reproducibility was checked using international standards (NIST SRM $3164)$ and by monitoring the $(235 / 238)$ ratios in the samples to be within the naturally abundant ratio (137.5). Uranium, thorium, barium and a range of trace elements were also determined via mass spectrometry using the same instrument.

\section{Quality Assurance}

Accuracy of the gamma spectrometry data was assessed in several ways: i) by running several bone samples that were known to be older than 75,2000 years (Pleistocene mammoth teeth from the Kennet Valley, U.K). These showed 230Th $=226 \mathrm{Ra}=210 \mathrm{~Pb}$ within uncertainty (mean $+/-0.98 \%$ ); (ii) 
803

804

805

806

807

808

809

810

811

812

813

814

815

816

817

818

819

820

821

822

823

by running several NIST (SRM) international reference materials, NIST SRM 4356, 3159, 3164, which were within $0.64-0.98 \%$ specific activities for all nuclides peaks.

Determination of 232 Th by mass spectrometry is very accurate $(<0.1 \%$ uncertainty). However, determination of the $230 / 232$ mass ratio using a single collector instrument poses problems of detecting enough of the low mass abundance 230 and long count times can lead to instrumental drift. Samples were analysed on the mass spectrometer and on the gamma detector such that a comparison of the calculated 230Th concentrations could be compared. There was a clear linear correlation between the two independent sets of data indicating that the mass spectrometry data was indeed accurate and that little mass drift was occurring during analysis.

Age determination U-Th

The U-Th ages determined using the equations above for samples with 232Th (detrital) concentrations lower than $25 \mathrm{mg} / \mathrm{kg}$. Isochrons were also constructed for some samples to check the integrity of the ages. Sub-samples of the same age from the same sample will show variations in 238U/232Th or $234 \mathrm{U} / 232 \mathrm{Th}$ but the $230 \mathrm{Th} / 232 \mathrm{Th}$ will only vary as a function of time and therefore plots of $238 \mathrm{U} / 232 \mathrm{Th}$ versus $230 \mathrm{Th} / 232 \mathrm{Th}$ will produce linear correlations which can be used to determine the age. ISOPLOT (v. 4.15) was used to construct 3D isochrones. Correlated errors were reduced by calculating isochron ages in ISOPLOT v4.15 (Ludwig, 2008).

References

Ivanovich, M. and Harmon, R. S. (Eds.) 1992 Uranium Series Disequilibrium Applications to Environmental Problems, Oxford: Oxford University Press.

Ludwig, K. R. 2008 Isoplot User's Manual. Berkeley Geochronology Cen

824

Table C1. Gamma Ray Intensities and Efficiencies for Detectors used in this study

\begin{tabular}{|c|c|c|c|c|c|c|}
\hline Radionuclide & $\begin{array}{c}\text { Energy } \\
\text { (keV) }\end{array}$ & $\begin{array}{c}\text { 제] } \\
\text { intensity (\%) }\end{array}$ & $\begin{array}{c}\text { Efficiency* } \\
\text { (\%) }\end{array}$ & $\begin{array}{c}\text { Interfering } \\
\text { ? }\end{array}$ & $\begin{array}{c}\text { Interfering } \\
\text { Energy (keV) }\end{array}$ & $\begin{array}{c}\text { Interfering } \\
\text { Intensity (\%) }\end{array}$ \\
\hline \multicolumn{7}{|l|}{${ }^{238}$ U-Series } \\
\hline${ }^{234} \mathrm{Th}$ & 63.3 & 3.81 & 45 & - & & - \\
\hline${ }^{234 \mathrm{~m}} \mathrm{~Pa}$ & 1001.0 & 0.82 & 9 & - & & - \\
\hline${ }^{234} \mathrm{U}$ & 53.2 & 0.119 & 38 & ${ }^{214} \mathrm{~Pb}$ & 53.2 & 1.10 \\
\hline${ }^{234} U$ & 120.9 & 0.041 & 22 & ${ }^{223} \mathrm{Ra}$ & 122.2 & 0.054 \\
\hline${ }^{230} \mathrm{Th}$ & 67.7 & 0.376 & 55 & - & & - \\
\hline${ }^{226} \mathrm{Ra}$ & 186.1 & 3.28 & 19 & ${ }^{235} \mathrm{U}$ & 185.7 & 2.4 \\
\hline${ }^{214} \mathrm{~Pb}$ & 53.2 & 1.10 & 38 & ${ }^{234} \mathrm{U}$ & 53.2 & 0.119 \\
\hline${ }^{214} \mathrm{~Pb}$ & 241.9 & 7.46 & 17 & ${ }^{234} \mathrm{Ra}$ & 240.8 & 3.9 \\
\hline${ }^{214} \mathrm{~Pb}$ & 295.1 & 19.2 & 16 & - & & - \\
\hline${ }^{214} \mathrm{~Pb}$ & 351.9 & 37.1 & 15 & - & & - \\
\hline
\end{tabular}




$\begin{array}{lccc}{ }^{214} \mathrm{Bi} & 609.3 & 46.1 & 13 \\ { }^{214} \mathrm{Bi} & 1120.2 & 15.0 & 7 \\ { }^{214} \mathrm{Bi} & 1764.5 & 15.9 & 5 \\ { }^{210} \mathrm{~Pb} & 46.5 & 4.05 & 31\end{array}$

\begin{tabular}{|c|c|c|c|c|c|c|}
\hline \multicolumn{7}{|c|}{${ }^{235} \mathrm{U}$-Series } \\
\hline${ }^{235} U$ & 163.3 & 0.21 & 20 & - & & - \\
\hline${ }^{235} \mathrm{U}$ & 185.5 & 2.40 & 19 & ${ }^{226} \mathrm{Ra}$ & 186.1 & 3.28 \\
\hline${ }^{235} \mathrm{U}$ & 205.3 & 0.21 & 18 & - & & - \\
\hline \multicolumn{7}{|c|}{${ }^{232} \mathrm{Th}$-Series } \\
\hline${ }^{228} \mathrm{AC}$ & 911.1 & 28.0 & 10 & - & & - \\
\hline${ }^{224} \mathrm{Ra}$ & 240.8 & 3.9 & 17 & ${ }^{214} \mathrm{~Pb}$ & 241.9 & 7.46 \\
\hline${ }^{212} \mathrm{~Pb}$ & 238.6 & 43.6 & 17 & - & & - \\
\hline${ }^{212} \mathrm{~Pb}$ & 727.3 & 6.65 & 11 & & & \\
\hline${ }^{208} \mathrm{Tl}$ & 583 & 86.0 & 12 & - & & \\
\hline
\end{tabular}

831

\begin{tabular}{|c|c|c|c|c|c|c|c|c|}
\hline & $\begin{array}{c}{ }^{210} \mathrm{~Pb} \\
(\mathrm{mBq} g)\end{array}$ & $\begin{array}{c}{ }^{226} \mathrm{Ra} \\
(\mathrm{mBq} / \mathrm{g})\end{array}$ & $\begin{array}{c}{ }^{230} \mathrm{Th} \\
(\mathrm{mBq} / \mathrm{g})\end{array}$ & $\begin{array}{c}{ }^{232} \mathrm{Th} \\
(\mathrm{mBq} / \mathrm{g})\end{array}$ & $\begin{array}{c}{ }^{238} \mathrm{U} \\
(\mathrm{mBq} / \mathrm{g})\end{array}$ & $\begin{array}{c}{ }^{234} \mathrm{U} \\
(\mathrm{mBq} / \mathrm{g})\end{array}$ & $\begin{array}{c}U \\
\text { (ㅁg/kg) }\end{array}$ & $\begin{array}{c}\text { Th } \\
\text { (国 } / \mathrm{kg} \text { ) }\end{array}$ \\
\hline $\begin{array}{c}\text { Reported } \\
\text { Value }\end{array}$ & (20) & $\begin{array}{c}14.5 \pm \\
1.1\end{array}$ & $\begin{array}{c}0.52 \pm \\
0.03\end{array}$ & $\begin{array}{c}0.98 \pm \\
0.03\end{array}$ & $\begin{array}{c}0.63 \pm \\
0.02\end{array}$ & $\begin{array}{c}0.64 \pm \\
0.02\end{array}$ & $\begin{array}{c}50.6 \pm \\
1.6\end{array}$ & $\begin{array}{c}242.6 \pm \\
7.4\end{array}$ \\
\hline $\begin{array}{l}\text { This } \\
\text { Study (n } \\
=5)\end{array}$ & $\begin{array}{c}20.5 \pm \\
0.8\end{array}$ & $\begin{array}{c}14.4 \pm \\
1.5\end{array}$ & $\begin{array}{c}0.55 \pm \\
0.05\end{array}$ & $\begin{array}{l}1.00 \pm \\
0.06\end{array}$ & $\begin{array}{c}0.66 \pm \\
0.04\end{array}$ & $\begin{array}{c}0.67 \pm \\
0.09\end{array}$ & $\begin{array}{c}51.0 \pm \\
1.9\end{array}$ & $\begin{array}{c}244.1 \pm \\
5.8\end{array}$ \\
\hline
\end{tabular}

Table C2. U-series results for the NIST-SRM Bone Ash (4356). analysed bone fragments). Decay constants used during this study are: ${ }^{238} \mathrm{U}=1.55125 \times 10^{-10} \mathrm{yr}^{-1}$; ${ }^{235} \mathrm{U}=9.8485 \times 10^{-10} \mathrm{yr}^{-1} ;{ }^{230} \mathrm{Th}=9.1952 \times 10^{-6} \mathrm{yr}^{-1} ;{ }^{226} \mathrm{Ra}=4.332 \times 10^{-4} \mathrm{yr}^{-1} ;{ }^{210} \mathrm{~Pb}=0.0311387 \mathrm{yr}^{-}$

* Based on a combination of NIST-SRM 4356, 3159, 3164 and 1646 in a hydroxyapatite sample (Fisher ultra-pure $\mathrm{Ca}_{10}\left(\mathrm{PO}_{4}\right)_{6} \mathrm{OH}_{2}$ made into in a cylinder shape to match the dimensions of the 